Arch. Tierz., Dummerstorf 45 (2002) 1, 13-21

Institut für Tierzucht und Haustiergenetik, Justus-Liebig-Universität Gießen, Germany ${ }^{1}$, Roslin Institute Edinburgh, Scotland ${ }^{2}$, Institute of Zootechnics, Catholic University of S. Cuore Piacenza, Italy ${ }^{3}$, Lab. Genetica Bioquimica y Grupos Sanguineos Zaragoza, Spain ${ }^{4}$, Department of Zootecnics University Ankara, Turkey ${ }^{5}$

OLIVER JANN ${ }^{1}$, EVA-MARIA PRINZENBERG ${ }^{1}$, HORST BRANDT ${ }^{1}$, JOHN L. WILLIAMS ${ }^{2}$, PAOLO AJMONE-MARSAN ${ }^{3}$, PILAR ZARAGOZA ${ }^{4}$, CEYHAN ÖZBEYAZ ${ }^{5}$ and GEORG ERHARDT ${ }^{1}$

\title{
Intragenic haplotypes at the bovine CSN1S1 locus
}

\author{
Dedicated to Prof. Drs. h. c. Franz Pirchner PhD, on the occasion of his $75^{\text {th }}$ birthday
}

\begin{abstract}
Summary
A new alternative genotyping method based on PCR-SSCP was developed for direct differentiation of the CSN1S1 alleles $B$ and $C$ in the coding region. In addition a PCR-RFLP test based on a MaeIII restriction site in the promoter region of CSN1S1, reported in the literature as an alternative test for the differentiation of $C S N 1 S 1 * B$ and $C$ was used and the alleles named $b$ and $c$. Genotyping of 649 animals belonging to 17 European and Turkish cattle breeds showed differences in occurrence and frequency of the alleles. CSN1S1*B occurred in all breeds with frequencies varying from 0.50 in Anatolian Blackup to 1.0 in e.g. Ayrshire. CSN1S1*b on the other hand varied from 0.63 in Jersey, 0.97 in Ayrshire to 1.0 in e.g. Angler.

Comparison of the results from both typing methods and positions in the gene showed that both mutations do not always occur together. From the resulting four intragenic haplotypes $(B-b, B-c, C-c$ and $C-b) B-b$ is predominant in all breeds with frequencies varying from 0.3450 in Anatolian Black to 1.0 in Angler and Scottish Highland. The number of haplotypes varied from only one in Angler and Scottish Highland, two in Ayrshire, three in Asturian Valley and Turkish Grey Steppe to all four in the other 12 breeds. Correlation between allele frequencies and the geographic origin of the breeds was significant for the MaeIII promoter polymorphism.
\end{abstract}

Key Words: casein, haplotype, SSCP, cattle

\section{Zusammenfassung}

Titel der Arbeit: Intragene Haplotypen im bovinen $\alpha_{\mathrm{s} 1}$-Kasein Gen (CSN1S1)

Es wurde ein neuer auf PCR-SSCP basierender DNA-Test zur direkten Unterscheidung von $C S N 1 S 1{ }^{*} B$ und $C$ in der kodierenden Genregion entwickelt. Zusätzlich wurde ein PCR-RFLP Test auf der Basis einer MaeIII Schnittstelle in der Promotor Region des CSN1S1, der in der Literatur als alternativer Test für die Differenzierung der $C S N 1 S 1 * B$ und $C$ Varianten genannt wird, zur Typisierung derselben Tiere verwendet und die Allele als $b$ und $c$ bezeichnet. Die Genotypisierung von 649 Tieren aus 17 europäischen und türkischen Rinderpopulationen ergab Unterschiede im Auftreten und der Frequenz der Allele. CSN1S1*B trat in allen untersuchten Rassen mit Frequenzen zwischen 0,50 in Anatolischem Schwarzvieh und 1,0 in Ayrshire auf. An der anderen polymorphen Position variierten die CSN1S1*b Frequenzen zwischen 0,63 bei Jersey über 0,97 bei Ayrshire und 1,0 bei Angler .

Der Vergleich der Ergebnisse beider Typisierungsmethoden an den beiden Positionen im Gen zeigte, dass beide Austausche nicht in allen Fällen übereinstimmen. Von den sich daraus ergebenden vier intragenen Haplotypen ( $B-b, C-c, C-c$ und $C-b$ ) war $B-b$ in allen Rassen am häufigsten vertreten mit Frequenzen zwischen 0,3450 bei Anatolischem Schwarzvieh und 1,0 bei Angler und Schottischem Hochlandrind. Die Zahl nachweisbarer Haplotypen schwankte zwischen nur einem bei Angler und Schottischem Hochlandrind, zwei bei Ayrshire, drei bei Asturischem Niederungsvieh und Türkischem Grauen Steppenrind und bis zu allen vier möglichen bei den übrigen 12 untersuchten Rassen. Es wurden signifikante Korrelationen zwischen dem MaeIII Promotorpolymorphismus und der geographischen Herkunft der Rassen gefunden. 


\section{Introduction}

Variants of different milk protein genes in cattle are discussed in the context of studies regarding quantitative and qualitative traits and are used within evolutionary and diversity studies. For $\alpha s_{1}$-casein (CSN1S1) 9 alleles $\left(A, B, C, D, E_{\text {Yak }}, E_{\text {Bali }}, F, G, H\right)$ have been described within different cattle breeds, with $C S N 1 S{ }^{*} B$ being the predominant allele in Bos taurus and CSN1S1*C in Bos indicus and Bos grunniens breeds (EIGEL et al., 1984; FORMAGGIONI et al., 1999). The other alleles are rare in other breeds that have been studied. It has been postulated that $C S N 1 S 1{ }^{*} B$ has positive effects on milk yield (LIN et al., 1986), whereas higher milk protein content is found in animal heterozygous for CSN1S1*BC compared to BB homozygous animals (NGKWAI-HANG et al., 1990; ALEANDRI et al., 1990, BOVENHUIS et al., 1992). In Nordic cattle breeds LIEN et al. (1999) identified an allele frequency gradient with low frequency of $C S N 1 S 1 * B$ in native breeds to high frequency of $C S N 1 S 1 * B$ and loss of $C S N 1 S 1^{*} C$ in high selected dairy cattle. This is in agreement with the reported very high frequencies of $C S N 1 S 1 * B$ in breeds selected for milk production, up to fixation or nearly-fixation in Ayrshire, Angler, or Holstein Friesian (ERHARDT, 1993; IKONEN et al., 1996).

Development of several DNA tests for genotyping milk protein genes offered the possibility to type animals independent from age, sex, and lactation (LÉVEZIEL et al., 1988). SCHLEE \& ROTTMANN (1992) and DAVID \& DEUTCH (1992) developed allele specific PCR tests (ASPCR) for differentiation of CSN1S1*B and C, while LIEN et al. (1993) used an amplification created restriction site (ACRS) for HphI to discriminate between $\operatorname{CSN} 1 S 1^{*} B$ and $\operatorname{CSN} 1 S 1{ }^{*} C$. The latter test detects the causal nucleotide substitution inside exon 17 of the gene. KOCZAN et al. (1993) described a polymorphism in the promoter of the CSN1S1 gene affecting a MaeIII restriction site. The resulting PCR-RFLP test was suggested as an alternative to the ASPCR test for the differentiation of $C S N 1 S 1^{*} B$ and $C$. However, TURECKOVÁ et al. (2001) recently reported that in Czech and German Red Cattle the MaeIII promoter polymorphism is not always linked to the HphI ACRS in exon 17.

Single strand conformation polymorphism (SSCP) analysis is a rapid and sensitive screening technique, that allows mutation identification without restriction enzyme digests or special primers (ORITA et al., 1989). PCR-SSCP analysis for milk protein genotyping identified new alleles in both - endangered and production breeds - which were subsequently characterized by DNA sequencing (PRINZENBERG et al., 1999; CAROLI et al., 2001).

The aim of this study was to determine the occurrence of the two CSN1S1 polymorphisms described in different cattle breeds and to define intragenic haplotypes as genetic markers using a PCR-SSCP based DNA test for typing the causal nucleotide substitution in exon 17.

\section{Materials and Methods}

Sample collection: Blood samples of 649 animals belonging to 17 cattle breeds (Anatolian Black $n=13$, Jersey $n=43$, Chianina $n=32$, Casta Navarra $n=34$, Turkish Grey Steppe $n=17$, Maremmana n=39, Aberdeen Angus $n=36$, Piemontese $n=42$, Fighting Bull $n=36$, Asturian Valley $n=42$, Hereford $n=46$, Pezzata Rossa Italiana n=47, Charolais n=51, British Friesian n=38, Ayrshire n=48, Angler $n=46$, Scottish Highland $n=39$ ) were collected and DNA was extracted by the method of MONTGOMERY and SISE (1990). 
DNA test (PCR-RFLP) for CSN1S1 promoter polymorphism: A 310 bp fragment containing the first 274 bp of the promoter and parts of exon 1 was amplified, digested with MaeIII and separated on an agarose gel as described by KOCZAN et al. (1993). Uncut fragments of the 310 bp fragment (indicating $G$ in nucleotide position 1957) were named $c$, fragments cut by MaeIII (indicating A in nucleotide position 1957) were named $b$.

$P C R-S S C P$ test for CSN1S1*B and C: For differentiation of the CSN1S1 alleles $B$ and $C$ a SSCP-based DNA test was developed using 58 DNA samples from animals with known CSN1S1 genotypes as standard samples. Genomic DNA was amplified by PCR to give a 223 bp-fragment containing exon 17 of the CSN1S1 gene (Position 1764417867) of GenBank Acc. No. 59856). PCR was in a final volume of $25 \mu$ l, containing 100 ng genomic DNA, 15 pmol of each primer (CSN1S1-5: $5{ }^{`}$ CAC TGT TGC TTT TTC AAT GGT C 3`CSN1S1-3: 5`AAG GCA ACA ATA TGC AGT CAT TT 3`), 1 U Taq-polymerase (Peqlab Biotechnologie GmbH, Erlangen), $200 \mu \mathrm{M} d N T P, 1.5 \mathrm{mM}$ $\mathrm{MgCl}_{2}, 10 \mathrm{mM}$ Tris- $\mathrm{HCl} \mathrm{pH}$ 8.8, $50 \mathrm{mM} \mathrm{KCl}$ with an initial denaturation step at $94^{\circ} \mathrm{C}$ for $5 \mathrm{~min}$, followed by 30 cycles with a denaturation at $94^{\circ} \mathrm{C}$ for $1 \mathrm{~min}$, annealing of $56^{\circ} \mathrm{C}$ for $1 \mathrm{~min}$, elongation of $72^{\circ} \mathrm{C}$ for $1 \mathrm{~min}$ and a final elongation of $72^{\circ} \mathrm{C}$ for $5 \mathrm{~min}$. Four microlitres of the PCR product were mixed with $6 \mu$ l formamide buffer (95\% formamide, $0.025 \%$ bromphenolblue, $0.025 \%$ xylenecyanol FF, $20 \mathrm{mM}$ EDTA), denatured at $91^{\circ} \mathrm{C}$ for $3 \mathrm{~min}$ and immediately chilled on ice. Samples were run $3 \mathrm{~h}$ at $200 \mathrm{~V}$ at $10^{\circ} \mathrm{C}$ on a $10 \%$ acrylamide:bisacrylamide gel (37:1) with $2 \%$ glycerol. DNA fragments were visualised by silver staining (BASSAM et al., 1991).

Haplotype definition: Haplotypes were determined based on the results of PCR-RFLP analyses determining nucleotide position (nt) 1957 (b=nt1957: A, c=nt1957: G) and exon 17 PCR-SSCP discriminating alleles B and C (Table 1).

Table 1

Nucleotide sequence of the bovine $C S N 1 S 1{ }^{*} B-b, C S N 1 S 1{ }^{*} B-c$, $C S N 1 S 1{ }^{*} C-c$, and $C S N 1 S 1{ }^{*} C-b$ haplotypes at the positions 17807 (corresponding to aminoacid 192) and 1957 of the sequence (numbering as published in GenBank Accession No. X59856) (Nukleotidsequenz der bovinen CSN1S1*B-b, CSN1S1*B-c, CSN1S1*C-c und CSN1S1*C-b Haplotypen an Position 17807 (entspricht Aminosäure 192) und 1957 der Sequenz Accession-Nr. $\mathrm{X} 59856)$

\begin{tabular}{l|cccc}
\hline & & \multicolumn{3}{|c}{ Haplotype } \\
Sequence position & CSN1S1*B-b & CSN1S1*B-c & CSN1S1*C-c & CSN1S1*C-b \\
\hline Nucleotide position 17807 & $G A A$ & $G A A$ & $G G A$ & $G G A$ \\
Amino acid position 192 & Glu & Glu & Gly & Gly \\
Nucleotide position 1957 & A & G & G & A \\
\hline
\end{tabular}

Data analysis: Allele frequencies, observed and expected genotype frequencies, and deviations from Hardy-Weinberg equilibrium were evaluated by GENEPOP Software (RAYMOND and ROUSSET, 1995). Expected and observed haplotype frequencies were calculated and compared ( $\chi^{2}$-values) with EH software (XIE and OTT, 1993). Correlations between degree of latitude and allele frequencies and linear regressions of allele frequencies on geographic latitude were calculated.

\section{Results}

PCR-SSCP analysis for CSN1S1 exon 17 showed two distinct fragment patterns for alleles $B$ and $C$ which was in agreement for all 58 DNA samples of known genotypes (Figure 1). 


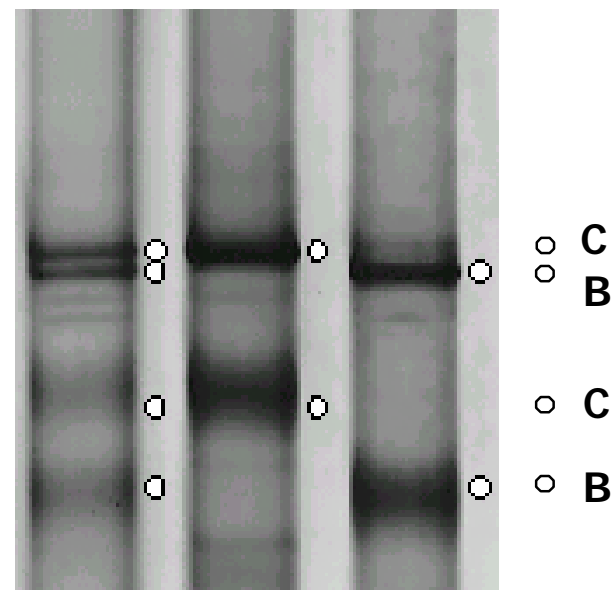

\section{BC CC BB}

Fig. 1: PCR-SSCP based DNA test for $C S N 1 S 1{ }^{*} B$ and $C S N 1 S 1{ }^{*} C$. Position of corresponding bands are marked by dots (PCR-SSCP DNA-Test für $C S N 1 S 1{ }^{*} B$ und $C S N 1 S 1{ }^{*} C$. Die Lage der entsprechenden Banden ist durch Punkte gekennzeichnet)

\section{Genotype frequencies}

The observed and expected genotype frequencies and the probability-values for HardyWeinberg equilibrium are shown in Table 2. All populations were in Hardy-Weinberg equilibrium at CSN1S1 locus for position 17807 and position 1957 except Pezzata Rossa and Piemontese for the first locus, where an excess of homozygous genotypes was observed. All of the expected six genotypes at the CSN1S1 locus were observed in eight of the 17 breeds analysed while in Scottish Highland and Angler only two genotypes were found.

Table 2

Observed (obs) and expected (exp) genotypes and probability-values (p) for Hardy-Weinberg equilibrium at CSN1S1 locus in European and Turkish cattle breeds (Beobachtete (obs) und erwartete (exp) Genotypen und Wahrscheinlichkeitswerte für Hardy-Weinberg Gleichgewicht am CSN1S1 Genort in europäischen und türkischen Rinderrassen)

\begin{tabular}{|c|c|c|c|c|c|c|c|c|c|c|c|c|c|c|}
\hline \multirow{3}{*}{ Breed } & \multicolumn{7}{|c|}{ CSN1S1 Position 17807} & \multicolumn{7}{|c|}{ CSN1S1 Position 1957} \\
\hline & \multicolumn{2}{|c|}{$B B$} & \multicolumn{2}{|c|}{$B C$} & \multicolumn{2}{|c|}{$C C$} & \multirow[t]{2}{*}{$\mathbf{p}$} & \multicolumn{2}{|c|}{$\boldsymbol{b} \boldsymbol{b}$} & \multicolumn{2}{|c|}{$b c$} & \multicolumn{2}{|c|}{ cC } & \multirow[t]{2}{*}{$\mathbf{p}$} \\
\hline & obs & exp & obs & $\exp$ & obs & exp & & obs & exp & obs & $\exp$ & obs & exp & \\
\hline Aber. Angus & 24 & 23.2 & 10 & 11.4 & 2 & 1.3 & 0.59 & 21 & 20.9 & 13 & 13.2 & 2 & 1.9 & 1.00 \\
\hline Anat. Black & 2 & 3.1 & 9 & 6.8 & 2 & 3.1 & 0.30 & 6 & 6.1 & 6 & 5.8 & 1 & 1.1 & 1.00 \\
\hline Angler & 46 & 46.0 & 0 & 0.0 & 0 & 0.0 & - & 46 & 46.0 & 0 & 0.0 & 0 & 0.0 & - \\
\hline Astur. Valley & 23 & 25.1 & 19 & 14.9 & 0 & 2.1 & 0.09 & 35 & 35.3 & 7 & 6.5 & 0 & 0.3 & 1.00 \\
\hline Ayrshire & 48 & 48.0 & 0 & 0.0 & 0 & 0.0 & - & 45 & 45.0 & 3 & 2.9 & 0 & 0.0 & 1.00 \\
\hline Brit. Friesian & 35 & 35.0 & 3 & 2.9 & 0 & 0.0 & 1.00 & 35 & 35.0 & 3 & 2.9 & 0 & 0.0 & 1.00 \\
\hline Cas. Navarra & 24 & 23.8 & 9 & 9.4 & 1 & 0.8 & 1.00 & 14 & 15.4 & 18 & 15.1 & 2 & 3.5 & 0.43 \\
\hline Charolais & 40 & 40.4 & 11 & 9.9 & 0 & 0.6 & 1.00 & 42 & 42.4 & 9 & 8.3 & 0 & 0.4 & 1.00 \\
\hline Chianina & 22 & 21.8 & 9 & 9.3 & 1 & 0.9 & 1.00 & 18 & 17.2 & 11 & 12.7 & 3 & 2.2 & 0.65 \\
\hline Fighting Bull & 31 & 30.2 & 4 & 5.6 & 1 & 0.2 & 0.20 & 25 & 24.1 & 9 & 10.8 & 2 & 1.1 & 0.30 \\
\hline Hereford & 34 & 33.0 & 10 & 12.0 & 2 & 1.0 & 0.26 & 42 & 42.1 & 4 & 3.9 & 0 & 0.1 & 1.00 \\
\hline Jersey & 15 & 16.8 & 24 & 20.3 & 4 & 5.8 & 0.33 & 15 & 16.8 & 24 & 20.3 & 4 & 5.8 & 0.38 \\
\hline Maremmana & 25 & 25.4 & 13 & 12.3 & 1 & 1.4 & 1.00 & 25 & 25.5 & 13 & 12.3 & 1 & 1.4 & 1.00 \\
\hline Pezz. Rossa & 40 & 38.4 & 5 & 8.2 & 2 & 0.4 & 0.04 & 42 & 42.1 & 5 & 4.8 & 0 & 0.1 & 1.00 \\
\hline Piemontese & 32 & 29.9 & 7 & 11.1 & 3 & 0.9 & 0.04 & 28 & 26.6 & 11 & 13.7 & 3 & 1.6 & 0.33 \\
\hline Sc. Highland & 39 & 39.0 & 0 & 0.0 & 0 & 0.0 & - & 39 & 39.0 & 0 & 0.0 & 0 & 0.0 & - \\
\hline T. Grey Steppe & 7 & 7.6 & 9 & 7.7 & 1 & 1.7 & 0.61 & 13 & 13.2 & 4 & 3.6 & 0 & 0.2 & 1.00 \\
\hline
\end{tabular}




\section{Allele and haplotype frequencies}

Table 3 gives the allele and haplotype frequencies at the CSN1S1 locus and shows differences both in the occurrence and the frequencies of the alleles and the haplotypes in the cattle breeds studied. $C S N 1 S 1 * B$ occurred in all breeds with frequencies varying from 0.50 in Anatolian Black to 1.0 in Ayrshire, Scottish Highland, and Angler. $C S N 1 S 1 * b$ on the other hand varied from 0.63 in Jersey, 0.97 in Ayrshire to 1.0 in Angler and Scottish Highland.

In most breeds frequencies for $C S N 1 S 1 * b$ are higher than for $C S N 1 S 1 * B$. In contrast, in Aberdeen Angus, Ayrshire, Casta Navarra, Chianina, Piemontese, and Turkish Grey Steppe CSN1S1*b occurs in lower frequencies than $B$.

From the four intragenic haplotypes $(B-b, B-c, C-c$ and $C-b) B-b$ is predominant in all breeds with frequencies varying from 0.3450 in Anatolian Black to 1.0 in Angler and Scottish Highland. Beside these two breeds, where only one haplotype occurs, in Ayrshire two haplotypes $(B-b$ and $B-c)$, and in Asturian Valley and Turkish Grey Steppe breed three haplotypes $(B-b, C-c$ and $C-b)$ are present, while four haplotypes occur in the other breeds. A $\chi^{2}$-test comparing expected and observed haplotype frequencies of position 17807 and position 1957 shows highly significant disequilibrium $(\mathrm{p}<0.01)$ in Aberdeen Angus, Asturian Valley, Charolais, Jersey and Piemontese and a significant disequilibrium $(\mathrm{p}<0.05)$ in British Friesian.

Table 3

Allele frequencies, expected, and observed haplotype frequencies of CSN1S1 in European cattle populations and corresponding $\chi^{2}$-value (Allelfrequenzen, erwartete und beobachtete Haplotypenfrequenzen von CSN1S1 in europäischen Rinderpopulationen und entsprechende $\chi^{2}$-Werte)

\begin{tabular}{|c|c|c|c|c|c|c|c|c|c|c|c|c|c|c|}
\hline \multirow{3}{*}{ Breed } & \multirow{3}{*}{$\mathbf{N}$} & \multirow{2}{*}{\multicolumn{4}{|c|}{ allele frequencies }} & \multicolumn{8}{|c|}{ haplotype frequencies } & \multirow{3}{*}{$\chi^{2}$} \\
\hline & & & & & & \multicolumn{4}{|c|}{ expected } & \multicolumn{4}{|c|}{ observed } & \\
\hline & & $\boldsymbol{B}$ & $C$ & $\boldsymbol{b}$ & $c$ & $B-b$ & $B-C$ & $C-c$ & $C-b$ & $B-b$ & $B-c$ & $C-c$ & $C-b$ & \\
\hline Aber. Angus & 36 & 0.81 & 0.19 & 0.76 & 0.24 & 0.6156 & 0.1944 & 0.0456 & 0.1444 & 0.7342 & 0.0714 & 0.1648 & 0.0297 & 22.33 \\
\hline Anat. Black & 13 & 0.50 & 0.50 & 0.69 & 0.31 & 0.3450 & 0.1550 & 0.1550 & 0.3450 & 0.3450 & 0.1550 & 0.1550 & 0.3450 & 0.00 \\
\hline Angler & 46 & 1.00 & 0.00 & 1.00 & 0.00 & 1.0000 & 0.0000 & 0.0000 & 0.0000 & 1.0000 & 0.0000 & 0.0000 & 0.0000 & - \\
\hline Astur. Valley & 42 & 0.77 & 0.23 & 0.92 & 0.08 & 0.7084 & 0.0616 & 0.0184 & 0.2116 & 0.7857 & 0.1429 & 0.0714 & 0.0000 & 12.00 \\
\hline Ayrshire & 48 & 1.00 & 0.00 & 0.97 & 0.03 & 0.9700 & 0.0300 & 0.0000 & 0.0000 & 0.9688 & 0.0313 & 0.0000 & 0.0000 & - \\
\hline Brit. Friesian & 38 & 0.96 & 0.04 & 0.96 & 0.04 & 0.9216 & 0.0384 & 0.0016 & 0.0384 & 0.9472 & 0.0133 & 0.0261 & 0.0133 & 8.14 \\
\hline Cas. Navarra & 34 & 0.84 & 0.16 & 0.68 & 0.33 & 0.5712 & 0.2772 & 0.0528 & 0.1088 & 0.6397 & 0.2132 & 0.1101 & 0.0368 & 5.45 \\
\hline Charolais & 51 & 0.89 & 0.11 & 0.91 & 0.09 & 0.8099 & 1 & 99 & 01 & 0 & 01 & 81 & 98 & 25.96 \\
\hline Chianina & 32 & 0.83 & 0.17 & 0.73 & 0.27 & 0.6059 & 0.2241 & 0.0459 & 0.1241 & 0.5781 & 0.2969 & 0.0000 & 0.1250 & 4.72 \\
\hline Fighting Bull & 36 & 0.92 & 0.08 & 0.82 & 0.18 & 0.7544 & 0.1656 & 0.0144 & 0.0656 & 0.7723 & 0.1443 & 0.0362 & 0.0471 & 1.52 \\
\hline Hereford & 46 & 0.85 & 0.15 & 0.96 & 0.04 & 0.8160 & 0.0340 & 0.0060 & 0.1440 & 0.8079 & 0.0399 & 0.0036 & 0.1486 & 0.06 \\
\hline Jersey & 43 & 0.63 & 0.37 & 0.63 & 0.37 & 0.3969 & 0.2331 & 0.1369 & 0.2331 & 0.5232 & 0.1513 & 0.2674 & 0.0582 & 12.97 \\
\hline Maremmana & 39 & 0.83 & 0.17 & 0.81 & 0.19 & 0.6723 & 0.1577 & 0.0323 & 0.1377 & 0.7120 & 0.1085 & 0.0966 & 0.0829 & 7.16 \\
\hline Pezz. Rossa & 47 & 0.90 & 0.10 & 0.95 & 0.05 & 0.8550 & 0.0450 & 0.0050 & 0.0950 & 0.8813 & 0.0230 & 0.0302 & 0.0655 & 4.81 \\
\hline Piemontese & 42 & 0.85 & 0.15 & 0.80 & 0.20 & 0.6800 & 0.1700 & 0.0300 & 0.1200 & 0.7472 & 0.0981 & 0.1043 & 0.0505 & 13.50 \\
\hline Sc. Highland & 39 & 1.00 & 0.00 & 1.00 & 0.00 & 1.0000 & 0.0000 & 0.0000 & 0.0000 & 1.0000 & 0.0000 & 0.0000 & 0.0000 & - \\
\hline T. Grey Steppe & 17 & 0.88 & 0.12 & 0.68 & 0.32 & 0.5984 & 0.2816 & 0.0384 & 0.0816 & 0.6765 & 0.0000 & 0.1176 & 0.2059 & 6.05 \\
\hline
\end{tabular}

$(\chi 2$-limit for $1 \%$ significance level is 11.34 and for $5 \%$ level is 7.81 . In breeds marked with "_" no $\chi 2$-analysis has been done due to fixation of one or two of the loci.)

\section{Correlations and regression analyses with geographic data}

Frequencies for $\operatorname{CSN} 1 S 1 * B$ and $b$ could be shown to be increasing from southern sampling area (Turkey) to northern Europe (Scotland). Correlation of geographic 
latitude in the range of the sampling area $\left(37^{\circ}-58^{\circ} \mathrm{N}\right)$ with $C S N 1 S 1^{*} B$ allele frequencies was $\mathrm{r}=0.417$ (n.s.), and $\mathrm{r}=0.556(\mathrm{p}<0.05)$ for $C S N 1 S 1^{*} b$.

Regression analysis resulted in a regression equitation of $y=0.00843 * x+0.45308$ for $C S N 1 S 1 * B$ and of $\mathrm{y}=0.01103^{*} \mathrm{x}+0.31914$ for $C S N 1 S 1 * b$ allele frequencies and geographic latitude (Figure 2).

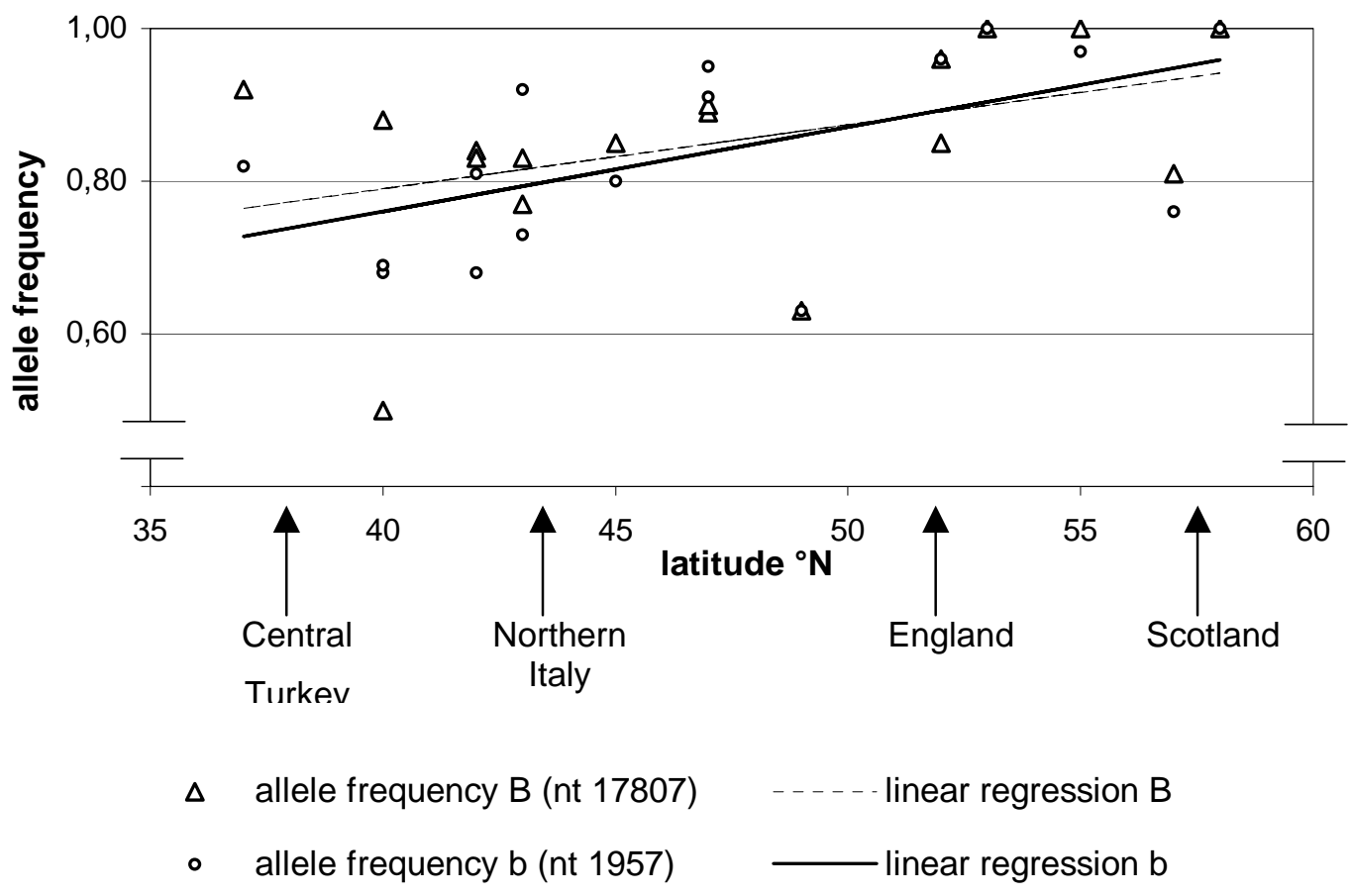

Fig. 2: Regression analysis of $\operatorname{CSN}_{1 S}{ }^{*} B\left(\mathrm{y}=0.00843^{*} \mathrm{x}+0.45308\right)$ and $b\left(\mathrm{y}=0.01103^{*} \mathrm{x}+0.31914\right)$ allele frequencies and geographic latitude (Regressionsanalyse von $\operatorname{CSN}_{1 S 1}{ }^{*} B\left(\mathrm{y}=0,00843^{*} \mathrm{x}+0,45308\right)$ und b $(y=0,01103 * x+0,31914)$ Allelfrequenzen und geographischer Breite $)$

\section{Discussion}

The PCR-SSCP test developed for the differentiation of CSN1S1 ${ }^{*} B$ and $C$ offers a rapid and cost-effective alternative to the ASPCR described by SCHLEE and ROTTMANN (1992) and DAVID and DEUTCH (1992) and the ACRS method described by LIEN et al. (1993). Our genotyping results show, in agreement with TURECKOVÀ et al. (2001), that the promoter polymorphism described by KOCZAN et al. (1993) can not be used as a reliable genotyping method to infer $C S N 1 S 1^{*} B$ and $C$-genotypes in all breeds. The small number of animals analysed by KOCZAN et al. (1993) belonged to Jersey, Holstein Friesian and German Simmental.

Aberdeen Angus, Ayrshire, British Friesian, Charolais, Turkish Grey Steppe, Pezzata Rossa, and Piemontese show low frequencies for $B-c$ and $C-b$ haplotypes, while frequencies of same haplotypes are high in Chianina and Anatolian Black.

Our results support the occurrence of different intragenic haplotypes in milk protein genes, that might contribute to variation of different milk production traits (SCHILD and GELDERMANN 1996; EHRMANN et al., 1997).

Expected and observed genotype frequencies at CSN1S1 nt 17807 in Piemontese and Pezzata Rossa were not in Hardy-Weinberg equilibrium. Both breeds showed much lower frequencies of heterozygous animals than expected from the allele frequencies. 
This may be a sampling artefact, however at position $n t 1957$ all breeds were in HardyWeinberg equilibrium.

Despite of close genetic linkage $\chi^{2}$-test for linkage disequilibrium does not show significant linkage in all populations. Linkage disequilibrium declines with increasing generations (FALCONER, 1984), so the level and extent of disequilibrium diminish in older populations. The British breed Ayrshire is a long established breed, as is the Hereford. Casta Navarra and Fighting Bull have also been maintained over many centuries. Maremmana represents a low-selected historic genotype, and Chianina is regarded to be the oldest Italian breed. Anatolian Black and Turkish Grey Steppe are very heterogenous breeds that remained without specific selection pressure over centuries (PORTER, 1991). Thus the limited linkage disequilibrium in these breeds points to the two mutations being very old. On the other hand Pezzata Rossa is a newly founded population (herdbook established in 1957) originating in crosses of Simmental with Friulana cattle. Simmental was planned to substitute Friulana by backcrossing, however its introgression stopped after a few generations. Haplotypes derived from both parental breeds are likely to be still present in the Pezzata Rossa and may cause the lack of linkage disequilibrium observed.

Frequencies of $C S N 1 S 1 * B$ are in tendency higher and significantly higher for $C S N 1 S 1 * b$ in northern than in southern European breeds, with highest values in dairy breeds of north western European origin. LIEN et al. (1999) reported an apparently contrary frequency gradient in Nordic breeds with high frequencies of $\operatorname{CSN} 1 S 1^{*} C$ in autochtone breeds of northern Scandinavia and lower frequencies to fixation in dairy breeds originated in southern Scandinavia. This indicates rather a selection gradient than a geographic gradient, supporting the suggestion made by LIN et al. (1986) that occurrence of $C S N 1 S 1 * B$ variant is correlated with selection for improvement in milk production traits. Our study analysed northern European cattle breeds, that include a large proportion of dairy breeds, selection pressure thus is expected to lead to increasing fixation of alleles linked to production traits. Allele frequencies of CSN1S1 show that in Anatolian Black both alleles $B$ and $C$ occur in equal frequency. LOFTUS et al. (1999) described a high admixture proportion of Bos indicus with $30.6 \%$ in Anatolian Black and BAKER \& MANWELL (1980) pointed out that $C S N 1 S 1{ }^{*} C$ occurs in very high frequencies in zebu cattle. Therefore the high frequency of $C S N 1 S 1 * C$ in Anatolian Black may have occurred by introgression of zebu genes.

However loss of haplotypes along a south-north gradient leading to fixation or nearly fixation of the CSN1S1 B-b haplotype in northern European cattle populations could be explained by drift. The loss of genetic diversity along a south-north gradient has already been described for a number of different loci. This may reflect distance from the center of domestication of cattle (MEDJUGORAC et al., 1994; TROY et al., 2001).

\section{Acknowledgements}

The authors thank Heike Wagner for technical assistance. This work was supported by the European Community (RESGEN-CT98-118).

\section{References}

ALEANDRI, R.; BUTTAZONI, L.G., SCHNEIDER, J.C.; CAROLI, A.; DAVOLI, R.:

The effects of milk protein polymorphisms on milk components and cheese-producing ability. J. Dairy

Sci. 73 (1990), 241-255 
BAKER, A.C.M.; MANWELL, C.:

Chemical classification of cattle: 1. Breed groups. Anim. Blood Grps. Biochem. Genet. 11 (1980), 127150

BASSAM, B.J.; CAETANO-ANOLLES, G.; GRESSHOFF, P.M.:

Fast and sensitive silver staining of DNA in polyacrylamide gels. Anal. Biochem. 196 (1991), 80-83

BOVENHUIS, H.; VAN ARENDONK, J.A.M.; KORVER, S.:

Associations between milk protein polymorphisms and milk production traits. J. Dairy Sci. 75 (1992), 2549-2559

CAROLI, A.; JANN, O.; BUDELLI, E.; BOLLA, E.; JÄGER, S.; ERHARDT, G.:

Genetic polymorphism of goat $\kappa$-casein (CSN3) in different breeds and characterisation at DNA-level. Anim. Genet. 32 (2001), 226-230

DAVID, V.A.; DEUTCH, A.H.:

Detection of bovine $\alpha$ s1-casein genomic variants using the allele-specific polymerase chain reaction. Anim. Genet. 23 (1992), 425-429

EIGEL, W.N.;BUTLER, J.E.; ERNSTROM, C.A.; FRRELL, H.M. jr.; HARWALKAR, V.R.; JENNES, R.;

McL. WHITNEY::

Nomenclature of Proteins of Cow’s milk: Fifth revision. J. Dairy Sci. 67 (1984), 1599-1631

ERHARDT, G.:

A new alpha S1-casein allele in bovine milk and its occurrence in different breeds. Anim. Genet. 24 (1993), 65-66

EHRMANN, S.; BARTENSCHLAGER, H.; GELDERMANN, H.:

Quantification of single gene effects on milk proteins in selected groups of dairy cows. J. Anim. Breed.

Genet. 114 (1997), 121-132

FALCONER, D.S.:

Einführung in die quantitative Genetik. (1984) Ulmer Verlag, Stuttgart

FORMAGGIONI, P.; SUMMER, A.; MALACARNE, M.; MARIANI, P.:

Milk protein polymorphism: Detection and diffusion of the genetic variants in Bos genus. Ann. Fac. Med.

Vet. Parma 19 (1999), 127-165

IKONEN, T.; RUOTTINEN, O.; ERHARDT, G.; OJALA, M.:

Allele frequencies of the major milk proteins in the Finnish Ayrshire and detection of a new kappa-casein variant. Anim. Genet. 27 (1996), 179-181

KOCZAN, D.; HOBOM, G.; SEYFERT, H.M.:

Characterization of the bovine alpha S1-casein gene C-allele, based on a MaeIII polymorphism. Anim. Genet. 24 (1993), 74

LEVEZIEL, H.; METENIER, L.; MAHE, M.-F.; CHOPLAIN, J.; FURET, J.-P.; PABOEF, G.; MERCIER, J.C.;

GROSCLAUDE, H.:

Identification of the two common alleles of bovine $\kappa$-casein locus by the RFLP-technique, using the enzyme HindIII. Génét. Sél. Evol. 20 (1988), 247-254

LIEN, S.; KAMINSKI, S.; ALESTROM, P.; ROGNE, S.:

A simple and powerful method for linkage analysis by amplification of DNA from single sperm cells. Genomics 16 (1993), 41-44

LIEN, S.; KANTANEN, J.; OLSAKER, I.; HOLM, L.E.; EYTHORSDOTTIR, E.; SANDBERG, K.; DALSGAID, B.; ADALSTEINSSON, S.:

Comparison of milk protein allele frequencies in Nordic cattle breeds. Anim. Genet. 30 (1999), 85-91

LIN, C.Y.; MCALLISTER, A.J.; NG-KWAI-HANG, K.F.; HAYES, J.F.:

Effects of milk protein loci on first lactation production in dairy cattle. J. Dairy Sci. 69 (1986), 704-712

LOFTUS, R.T., ERTUGRUL, O., HARBA, A.H., EL-BARODY, M.A., MACHUGH, D.E., PARK, S.D.,

BRADLEY, D.G.: A microsatellite survey of cattle from a centre of origin: the Near East. Mol Ecol. 8 (1999), 2015-2022

MEDJUGORAC, I.; KUSTERMANN W.; LAZAR, P.; RUSS I.; PIRCHNER, F.:

Marker-derived phylogeny of cattle supports demic expansion of agriculture. Anim. Genet. 25 (1994), 1927

MONTGOMERY G.W.; SISE, J.A.:

Extraction of DNA from sheep white blood cells. N Z J Agric. Res. 33 (1990), 437-441

NG-KWAI-HANG, K.F.; MONARDES, H.G.; HAYES, J.F.:

Association between genetic polymorphism of milk proteins and production traits during three lactations. J. Dairy Sci. 73 (1990), 3414-3420

ORITA, M.; SUZUKI, Y.; SEKIYA, T.; HAYASHI, K.:

Rapid and sensitive detection of point mutations and DNA polymorphisms using the polymerase chain reaction. Genomics 5 (1989), 874-879 
PORTER, V.:

Cattle - A Handbook to the Breeds of the World. (1991) Ed. by V. Porter, Facts on File, New York

PRINZENBERG, E.M.; KRAUSE, I., ERHARDT, G.:

SSCP analysis at the bovine CSN3 locus discriminates six alleles corresponding to known protein variants (A, B, C, E, F, G) and three new DNA polymorphisms (H, I, A ${ }^{1}$ ). Anim. Biotechnol. 10 (1999), 49-62

RAYMOND, M., ROUSSET F.:

GENEPOP (version 1.2): population genetics software for exact tests and ecumenicism. J. Hered. 86 (1995), 248-249

SCHILD, T.A.; GELDERMANN, H.:

Variants within the 5'-flanking regions of bovine milk-protein-encoding genes. III. Genes encoding the Ca-sensitive caseins $\alpha$ s1, $\alpha$ s2 and $\beta$. Theor. Appl. Genet. 93 (1996), 887-893

SCHLEE, P.; ROTTMANN, O.:

Determination of bovine $\alpha$ s1-casein alleles B and C by allele specific PCR. J. Anim. Breed. Genet. 109, (1992), 316-319

TROY, C.S.; MACHUGH, D.E.; BAILEY, J.F.; MAGEE, D.A.; LOFTUS, R.T.; CUNNINGHAM, P.;

CHAMBERLAIN, A.T.; BRYAN, C.S.; BRADLEY, D.G.: Genetic evidence for Near-Eastern origins of European cattle. Nature 410 (2001), 1088-1091

TURECKOVÁ, B.; REHOUT, V.; CITEK, J.; NEUBAEROVA, V.; JANDUROVÁ, O.:

The polymorfism of milk protein alleles in middle European red cattle populations. Proc. $52^{\text {nd }}$ Ann Meeting of the EAAP, Budaest, Hungary, 2001 (G4.23)

XIE, X.; OTT, J.:

Testing linkage disequilibrium between a disease gene and marker loci. Am. J. Human Genet. 53 (1993), 1107 (abstract)

Received: 2001-11-14

Accepted: 2001-12-20

Authors`addresses

Dipl. Ing. agr. OLIVER JANN, Dr. EVA-MARIA PRINZENBERG, apl. Prof. Dr. HORST BRANDT, Prof. Dr. GEORG ERHARDT

Institut für Tierzucht und Haustiergenetik der Justus-Liebig Universität

Ludwigstr. 21B

D-35390 Gießen / Germany

E-Mail: Georg.Erhardt@agrar.uni-giessen.de

Dr. JOHN L. WILLIAMS

Department of Genomics and Bioinformatics

Roslin Institute

Midlothian / Scotland EH25 9PS

Prof. Dr. PAOLO AJMONE-MARSAN

Institute of Zootechnics

Catholic University of S. Cuore

Via Emilia Parmense, 84

I-29100 Piacenza / Italy

Prof. Dr. PILAR ZARAGOZA

Lab. Genetica Bioquimica y Grupos Sanguineos

Facultad de Veterinaria

Universidad de Zaragoza

Miguel Servet 177

50013 Zaragoza / Spain

Prof. Dr. CEYHAN ÖZBEYAZ

A.Ü.Veteriner Fakültesi Dergisi

Fac. Vet. Med. Univ. Ankara

Ankara / Turkey 